\title{
Production and characterization of monoclonal antibodies against ochratoxin $B$
}

\author{
Alexandra H. Heussner ${ }^{a}$, Ines Moeller ${ }^{a}$, Billy W. Day ${ }^{b}$, \\ Daniel R. Dietrich ${ }^{a}$, Evelyn O'Brien ${ }^{\text {a,* }}$ \\ a Environmental Toxicology, University of Konstanz, P.O. Box X-918, 78457 Konstanz, Germany \\ b Pharmaceutical Sciences, University of Pittsburgh, Pittsburgh, PA 15261, USA
}

\begin{abstract}
Monoclonal antibodies against ochratoxin B (OTB) were generated by immunizing Balb/c mice with OTB conjugated to keyhole limpet hemocyanin $(\mathrm{KLH})$ via carbodiimide reactions with $\mathrm{CHMC}$ and EDAC. A stable hybridoma cell line $2 \mathrm{~F} 1 . \mathrm{E} 10$ was produced by fusion of murine splenocytes and myeloma cells. The obtained antibodies were characterized using an indirect competitive ELISA. The detection limit was calculated $(27 \pm 2 \mathrm{nM} \mathrm{OTB})$ and $50 \%$ binding inhibition was reached at $500 \mathrm{nM}$ free OTB. A low cross-reactivity to ochratoxin A (OTA) of $3.3 \%$ and no cross-reactivities to either coumarin or DL-phenylalanine were observed, suggesting a highly specific OTB antibody. The antibody type was identified as IgG class 1 with the light chain being of the $\kappa$ configuration.

These antibodies can be used in an indirect competitive ELISA to detect OTB in the nanomolar to micromolar concentration range and may be useful for the analysis of contaminated food items.
\end{abstract}

Keywords: Ochratoxin B; Monoclonal antibodies; ELISA

\section{Introduction}

Ochratoxins are a mycotoxin family of metabolites produced by certain ubiquitously occurring Aspergillus and Penicillium species. The toxins are common contaminants of human food and animal feed and are regularly found in human and animal serum samples (O'Brien and Dietrich, 2005b). Ochratoxins have been shown to be nephrotoxic, teratogenic and carcinogenic in various laboratory animals (O'Brien and Dietrich, 2005b) and appear to be the causal agents in mycotoxic porcine nephropathy (MPN)

Abbreviations: ELISA, enzyme-linked immunosorbent assay; HPLC, high performance liquid chromatography; FBS, fetal bovine serum; DMSO, dimethylsulfoxide; PBS, phosphate-balanced saline; PCR, polymerase chain reaction; BSA, bovine serum albumin; IgG, immunglobulin G; $\mathrm{IC}_{50}, 50 \%$ inhibitory concentration; RIA, radioimmunoassay.

Corresponding author. Tel.: +49 7531 884664; fax: +49 7531883170.

E-mail address: evelyn.obrien@uni-konstanz.de (E. O’Brien).
(Stefanovic et al., 2006; Stoev et al., 1998; Stoev et al., 2002). Furthermore, they are most likely involved in the etiology of a similar human disease, namely Balkan endemic nephropathy (BEN) (Pfohl-Leszkowicz et al., 2002; Stoev, 1998; Tatu et al., 1998). Ochratoxin A (OTA) is the most prominent family member, followed by ochratoxin B (OTB) (Fig. 1), which differs only by the substitution of the chloride by a hydrogen at the $\mathrm{C}_{5}$ of the isocoumarin moiety. OTB has often been reported to be less toxic than OTA in vivo and in vitro (Dietrich et al., 2001; Doster et al., 1974; Doster et al., 1972; O'Brien et al., 2001; Størmer et al., 1985). However, more recent in vitro data brings this into question (Heussner et al., 2006; Mally et al., 2005). The difference in structure is assumed to be responsible for the differences in toxicities and may indicate different modes of action (Mally et al., 2005; O'Brien et al., 2001; O'Brien and Dietrich, 2005b). OTA and OTB can occur simultaneously, as they are produced by the same species and to date several studies have 


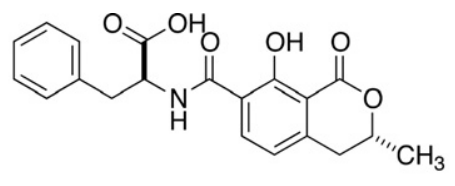

ochratoxin B

2(S)-[(8-Hydroxy-3(R)-methyl-1-oxoisochroman-7-carbonyl)amino]-3-phenylpropionic acid
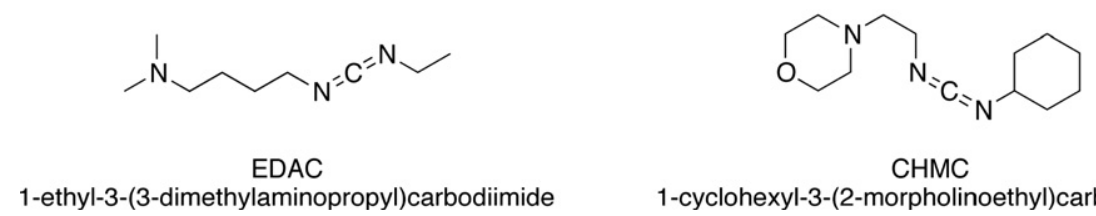

CHMC

1-cyclohexyl-3-(2-morpholinoethyl)carbodiimide

Fig. 1. Chemical structures of OTB and linkers. EDAC and CHMC are so-called "zero-length"-linkers. Their use results in a direct linkage between carrier and hapten without any residual of the linkers.

demonstrated synergistic or more-than-additive effects of these toxins in vitro and in vivo (Heussner et al., 2006; O'Brien and Dietrich, 2005a; O'Brien and Dietrich, 2005b). As the mechanism(s) of action of the individual toxins have yet to be elucidated, the reasons for these interactions remain unclear.

Based on these observations, a clear differentiation of OTA and OTB in biological samples would be advantageous in the generation of improved mechanistic understanding and for application of appropriate risk assessment models.

A highly reproducible and accurate method for this purpose is HPLC with fluorescence detection. However, this method requires specifically skilled personnel and expensive equipment. Alternatively, rapid and simpler immunological methods are widely used to detect ochratoxins in food or serum samples, but in the recent years, studies and developments have concentrated on the analysis of OTA (Cho et al., 2005; Chu, 1976; Gyongyosi-Horvath et al., 1996; Kawamura et al., 1989; Pestka et al., 1981; Rousseau et al., 1987; Yu et al., 2005) for which several test kits are on the market. There is, however, no commercially available OTB antibody.

Therefore, the present study aimed to produce and to characterize a specific monoclonal antibody against OTB to provide an analytic tool for the efficient differentiation between OTA and OTB in mixed samples. Furthermore, the generation of OTB-specific antibodies could aid the elucidation of the mode(s) of action of both toxins.

\section{Materials and methods}

\subsection{Chemicals and reagents}

Highly purified ochratoxin A and B ( $>98 \%$ purity, benzene free) were kindly provided by M.E. Stack, US FDA, Washington, DC Media, FBS and other cell culture reagents were purchased from PAA Laboratories $\mathrm{GmbH}$, Cölbe, Germany. $\left[{ }^{3} \mathrm{H}\right] \mathrm{OTB}$ with a specific activity of $1.85 \times$ $10^{11} \mathrm{~Bq} / \mathrm{mmol}$ (5 Ci/mmol) was purchased from ARC Inc., St. Louis, MO, USA. Unless otherwise stated, all other chemicals were purchased from Sigma-Aldrich GmbH, Seelze, Germany, and were of the highest quality commercially available.

\subsection{Experimental animals}

Female Balb/c mice were purchased from the breeding section of the animal research facility (TFA) at the University of Konstanz, Germany. Initially, mice were housed in groups of three per cage with feed and tap water ad libitum. Their general state of health was assessed daily and body weights were recorded weekly. Immunization started at an age of seven weeks. A total of twelve mice, divided into four antigen groups, were immunized. Animals receiving the same antigen were housed together in one cage and were distinguished by ear clips.

\subsection{Antigen preparation and characterization}

OTB was coupled to keyhole limpet hemocyanin (KLH) using each of the carbodiimides EDAC and CHMC (Fig. 1) at $37^{\circ} \mathrm{C}$ for $4 \mathrm{~h}$ as previously described (Baumgartner and Wilchek, 1955; Sheehan and Hess, 1955). In parallel, a KLH control (using only the vehicle, $0.6 \%(\mathrm{v} / \mathrm{v})$ DMSO, in deionized water) was prepared. The resulting complexes were dialyzed against deionized water $\left(3 \times 24 \mathrm{~h}, 4^{\circ} \mathrm{C}\right)$, lyophilized and stored at $-80^{\circ} \mathrm{C}$ until further use. For immunization, the conjugates were dissolved in PBS (1.7 $\mathrm{mM} \mathrm{NaH}_{2} \mathrm{PO}_{4}, 8.4 \mathrm{mM} \mathrm{Na}_{2} \mathrm{HPO}_{4}, 150 \mathrm{mM} \mathrm{NaCl}$, pH 7.4) to a nominal concentration of $10 \mu \mathrm{g} / \mathrm{ml}$ after determination of the total protein concentration using the bicinchoninic acid assay (BCA) according to the manufacturer's instructions. Before use, each antigen solution was proven to be free of microbiological contamination by LB agar incubation ( 2 days, $37^{\circ} \mathrm{C}$ ).

As the absorption maxima of OTB and KLH overlap, the ratio of bound compound to carrier could not be analyzed spectrophotometrically. Therefore, conjugation efficiency was estimated by preparing additional antigens in parallel, nominally spiked with $1 \times 10^{5} \mathrm{~Bq}\left[{ }^{3} \mathrm{H}\right] \mathrm{OTB} / \mathrm{sample}$, which were analyzed by liquid scintillation counting in triplicate.

\subsection{Immunization and blood sampling}

The antigens were emulsified with an equal volume of the Ribi adjuvant system (Sigma-Aldrich), containing monophosphoryl lipid A (MLP) and trehalose dicorynomycolate (TDM), immediately prior to injection. Two conjugates (OTB-EDAC-KLH and OTB-CHMC-KLH) and two controls (PBS and KLH) were injected subcutaneously in equal volumes at defined intervals. After priming with $75 \mu \mathrm{g}$ antigen (nominal) in a total volume of $150 \mu \mathrm{l}$ (including $50 \%$ (v/v) adjuvant) two boosts with and nine boosts without adjuvant were carried out on days 35 and 43 and 52, 59, 66, $73,81,91,101,111$ and 121, respectively. This scheme was used for all immunization groups with the following exception: the OTB-EDACKLH conjugate did not yield a sufficiently high protein concentration, therefore the amount of antigen per mouse was modified on day 1 to $45 \mu \mathrm{g}$ and on days 35 and 43 to $58 \mu \mathrm{g}$. For priming, only antigen batch 1 was 
Table 1

Protein contents of different antigen preparations

\begin{tabular}{lllll}
\hline Antigen & \multicolumn{4}{l}{ Total protein $(\mu \mathrm{g} / \mu \mathrm{l})$ of batch no. } \\
\cline { 2 - 5 } & 1 & 2 & 3 & Pooled \\
\hline PBS control & 0.00 & 0.00 & n.s. & 0.00 \\
KLH control & $3.73 \pm 0.52$ & $8.59 \pm 0.09$ & n.s. & $5.20 \pm 0.09$ \\
OTB-CHMC- & $1.00 \pm 0.14$ & $1.03 \pm 0.04$ & $1.32 \pm 0.19$ & $1.01 \pm 0.01$ \\
$\quad$ KLH & & & & \\
OTB-EDAC- & $0.60 \pm 0.02$ & $0.87 \pm 0.09$ & $1.07 \pm 0.02$ & $0.78 \pm 0.01$ \\
$\quad$ KLH & & & & \\
\hline
\end{tabular}

Data represent the means of three replicates \pm SD. n.s.: No sample prepared.

used and all further immunization steps were carried out with pooled batches of antigen solutions (Table 1).

Blood samples (approximately $0.1 \mathrm{ml}$ blood from the plexus retrobulbaris) were collected at defined intervals. To minimize the risk of blindness, each mouse served as blood donor only four times (McGill and Rowan, 1989). Sera were prepared by centrifugation (2000g, $10 \mathrm{mins})$ of the coagulated blood and stored as aliquots at $-20^{\circ} \mathrm{C}$ until further use.

\subsection{Cell preparations and culture conditions}

Myeloma cells (SP2/0-Ag14) were cultured in RPMI 1640 medium supplemented with $10 \%$ (v/v) FBS and antibiotics $(100 \mathrm{U} / \mathrm{ml}$ penicillin, $100 \mu \mathrm{g} / \mathrm{ml}$ streptomycin) under standard humidified conditions $\left(37^{\circ} \mathrm{C}\right.$, $95 \% \mathrm{O}_{2}, 5 \% \mathrm{CO}_{2}$ ). Revertants were eliminated via 8-azaguanine treatment ( $20 \mu \mathrm{g} / \mathrm{ml}$, three medium changes). For the fusion process, myeloma cells were seeded at a density of $1 \times 10^{5}$ cells $/ \mathrm{ml}$ in culture flasks and allowed to proliferate for four days resulting in a high yield of viable cells in logarithmic growth phase.

Peritoneal macrophages of untreated Balb/c mice were isolated via peritoneal lavage with PBS and seeded into 96-well plates $\left(1 \times 10^{3}\right.$ cells/well $)$ in supplemented RPMI 1640 medium (containing 10\% (v/v) FBS, antibiotics, $1 \mathrm{mM}$ sodium pyruvate and non-essential amino acids) for subsequent use as feeder cells for the hybridoma cells (Bazin and Lemieux, 1989).

B-lymphocytes from the spleens of immunized mice were isolated according to standard methods (Baumgarten, 1992) for fusion with the myeloma cells.

Myeloma cells $\left(2 \times 10^{7}\right)$ were fused with freshly isolated spleen cells $\left(1 \times 10^{8}\right)$ using $50 \%$ aqueous hydrophilic polyethylene glycol (PEG 1500) according to manufacturer's recommendations. After the fusion procedure, cells (in $144 \mathrm{ml}$ supplemented RPMI 1640) were seeded (50 $\mu \mathrm{l} /$ well) into 96-well plates containing the feeder cells. For hybridoma cell selection, standard HAT (hypoxanthine, aminopterin, thymidine) treatment was used (Baron, 1992). To ensure monoclonality, single cells producing the desired antibody were isolated from the mixture by limiting dilution cloning carried out essentially according to the method of $\mathrm{Oi}$ and Herzenberg (1980). Hybridoma clones, which tested positive for antibody production, were cloned again and then further expanded.

Cell viability was tested via standard Trypan blue exclusion assay. Absence of mycoplasma contamination was confirmed by the Hoechst 33342 staining assay (Hilwig and Gropp, 1972) and PCR (VenorGeM, Minerva Biolabs, Germany) in the myeloma cell line and in the resulting hybridoma cells. Both cell lines were cryopreserved according to the freezing protocol of Wuerzner et al. (1992) and stored in liquid nitrogen.

\subsection{Preparation and characterization of the $O T B-B S A$-conjugate for ELISA}

OTB (20 mg) was conjugated to BSA (40 mg) using $150 \mathrm{mg}$ EDAC as described for $\mathrm{KLH}$ above. After dialysis at $4{ }^{\circ} \mathrm{C}$ for $2 \times 24 \mathrm{~h}$ against phosphate buffer $\left(0.1 \mathrm{M} \mathrm{NaH}_{2} \mathrm{PO}_{4}, \mathrm{pH} 7.0\right)$ the conjugates were lyophilized, redissolved in $3 \mathrm{ml} 0.05 \mathrm{M}$ Tris buffer, $\mathrm{pH} 8.5$, and filtered through a Sephadex G-100 matrix at $4{ }^{\circ} \mathrm{C}$ according to the supplier's recommenda- tions to separate the coupled product from fragments. Elution was achieved with $36 \mathrm{ml}$ Tris buffer and $1 \mathrm{ml}$ fractions were collected.

OTB and BSA contents of the fractions were determined by UV spectrophotometry at $360 \mathrm{~nm}$ against a standard curve of serial dilutions of OTB in Tris buffer and by BCA protein assay, respectively. Due to the small amounts of eluate, only one sample per fraction could be measured. Conjugate peak fractions were pooled and dialyzed against deionized water $\left(2 \times 24 \mathrm{~h}, 4^{\circ} \mathrm{C}\right)$. Protein and OTB contents were re-determined and the conjugates were stored at $-20^{\circ} \mathrm{C}$ as aliquots.

\subsection{Sandwich ELISA}

This assay was used to measure the IgG titer of experimental animals (serum) and of the hybridoma supernatants. Microtiter plates (MaxiSorp ${ }^{\mathrm{TM}}$, Nunc, Wiesbaden, Germany) were coated with $1 \mu \mathrm{g} / \mathrm{ml} \mathrm{Fc} \gamma$-fragment specific goat anti-mouse IgG (Dianova, Hamburg, Germany) in carbonate buffer ( $32 \mathrm{mM} \mathrm{Na}_{2} \mathrm{CO}_{3}, 70 \mathrm{mM} \mathrm{NaHCO} 3, \mathrm{pH}$ 9.6) overnight at $4{ }^{\circ} \mathrm{C}$. Plates were washed with $3 \times 200 \mu \mathrm{l}$ washing buffer (PBS with $0.05 \%$ (v/v) Tween 20) per well then with $2 \times 200 \mu \mathrm{l}$ PBS and blocked for $1 \mathrm{~h}$ at $37^{\circ} \mathrm{C}$ with $300 \mu \mathrm{l}$ blocking buffer ( $1 \%(\mathrm{w} / \mathrm{v})$ casein in PBS). Serial dilutions of serum samples $(1: 100,000$ to $1: 100,000,000)$ and hybridoma supernatants $(1: 10$ to $1: 100,000)$ in blocking buffer were applied. A standard calibration curve of purified mouse IgG in blocking buffer was used for comparison.

Plates were incubated for $1 \mathrm{~h}$ at $37^{\circ} \mathrm{C}$ and thereafter washed again as described above. Then, $16 \mathrm{ng} / \mathrm{ml}$ HRP-conjugated goat anti-mouse IgG $\mathrm{F}\left(\mathrm{ab}^{\prime}\right) 2$-fragment specific antibodies (Dianova, Hamburg, Germany) were added and incubated for $1 \mathrm{~h}$ at $37^{\circ} \mathrm{C}$. After additional washing steps, TMB in the presence of $\mathrm{H}_{2} \mathrm{O}_{2}$ was used as substrate. The reaction was stopped after 15 min with $2 \mathrm{M} \mathrm{H}_{2} \mathrm{SO}_{4}$ and absorption was measured at $450 \mathrm{~nm}$ using a microtiter plate reader.

\subsection{Indirect ELISA}

This ELISA was used to screen for specific antibodies produced by hybridoma cells. Hybridoma culture supernatants were collected four days after the last medium change and diluted to yield $0.3 \mu \mathrm{g} / \mathrm{ml} \mathrm{IgG}$ in blocking buffer. Plates were coated with $100 \mu \mathrm{l} /$ well OTB-BSA (1:1000 dilution in carbonate buffer) overnight. Plates were washed and blocked as described above. Then, $100 \mu 1$ sample/well was incubated for $1 \mathrm{~h}$ at $37^{\circ} \mathrm{C}$. Plates were washed again and $100 \mu \mathrm{l} /$ well HRP-conjugated goat antimouse $\operatorname{IgG}$ ( $\mathrm{Fc} \gamma$-fragment specific, Dianova, Hamburg, Germany) in blocking buffer were applied and incubated for $1 \mathrm{~h}$ at $37^{\circ} \mathrm{C}$. Detection was performed as described above. A 1:200,000 serum dilution from OTBimmunized donor mice served as positive control. The same dilutions of PBS- and KLH-sera were used as negative controls to exclude falsenegative results due to high but unspecific antibody concentration. Blocking buffer and medium controls were also carried out.

\subsection{Indirect competitive ELISA}

To evaluate the detection range of the selected OTB-antibodies and the cross-reactivity to $\mathrm{KLH}$, a coupling adduct or to other structurally related molecules, an indirect ELISA was carried out using free OTB, OTA, EDAC, DL-phenylalanine and coumarin (each in serial dilutions ranging from $1 \mathrm{nM}$ to $100 \mu \mathrm{M}$ in PBS) as potential binding competitors. Each competition was carried out in duplicate using at least six concentrations (Fig. 4) and the values were compared to PBS alone. The degree of competition was calculated using the following formula:

$\%$ OTB binding $=\left(\right.$ Absorption $_{\mathrm{OTB}} /$ Absorption $\left._{\mathrm{PBS}}\right) \times 100$

The relative cross-reactivity was determined as

$\%$ cross-reactivity $=\left(\frac{50 \% \text { inhibitory concentration }(\mathrm{OTB})}{50 \% \text { inhibitory concentration }(\text { competitor })}\right) \times 100$. 


\subsection{Isotyping of monoclonal antibodies}

Isotyping was carried out with the mouse $\mathrm{mAb}$ isotyping test kit (HyCult Biotechnology, Uden, The Netherlands) according to manufacturer's recommendations.

\subsection{Data analysis}

Unless otherwise stated, data are presented as arithmetic means with standard deviations of at least three independent experiments carried out in duplicate. Calculations were performed using MS Excel 2000. GraphPad Prism 3.0 was used for curve generation and non-linear regression.

\section{Results}

\subsection{Antigen preparation and coupling ratio}

Antigens were prepared by coupling of OTB to KLH using EDAC or CHMC (Fig. 1). The coupled antigens showed high affinity for the dialysis tubing and the reaction tube walls. Therefore, only part of the total conjugates could be solubilized and their protein concentration determined. These are outlined in Table 1.

The efficiency of the coupling procedure as determined using $\left[{ }^{3} \mathrm{H}\right] \mathrm{OTB}$ is summarized in Table 2. Mean coupling ratios (KLH:hapten) of 1:34 and 1:24 were achieved for EDAC and CHMC, respectively.

\subsection{Characterization of $O T B-B S A$ conjugate for ELISA}

The analysis of the OTB-BSA conjugate resulted in $196 \mu \mathrm{g} / \mathrm{ml}(3 \mu \mathrm{M}$, monomers) BSA and $0.02 \mu \mathrm{M}$ OTB. Representative curves are shown in Fig. 2.

\subsection{General state of animals during immunization}

The recorded body weights (data not shown) did not indicate abnormalities in the development or general health

Table 2

Efficiency of antigen coupling via carbodiimides

\begin{tabular}{lllll}
\hline Antigen & $\begin{array}{l}\text { Protein } \\
(\mathrm{mg} / \\
\text { sample) }\end{array}$ & $\begin{array}{l}\text { Protein } \\
(\mathrm{nmol} / \\
\text { sample })^{\mathrm{a}}\end{array}$ & $\begin{array}{l}\text { Mean coupling } \\
\text { ratio } \\
\text { (protein:hapten) }\end{array}$ & $\begin{array}{l}\text { Coupled } \\
\text { hapten } \\
\text { (nmol/ } \\
\text { sample) }\end{array}$ \\
\hline $\begin{array}{l}\text { KLH } \\
\text { OTB-CHMC- } \\
\quad \text { KLH }\end{array}$ & 10.53 & 105.3 & $\begin{array}{l}\text { Control } \\
1: 24\end{array}$ & $\begin{array}{l}\text { Control } \\
670 \pm 200\end{array}$ \\
$\begin{array}{l}\text { OTB-EDAC- } \\
\text { KLH }\end{array}$ & 2.37 & 28.2 & $1: 34$ & $810 \pm 20$ \\
\hline
\end{tabular}

Due to low sample volumes, samples were divided into four parts. One part was used for protein determination and three parts were used to measure the $\left[{ }^{3} \mathrm{H}\right] \mathrm{OTB}$ content as pseudo-replicates. Therefore, standard deviations could only be provided for the latter data.

${ }^{\text {a }} \mathrm{KLH}$ is a polymeric protein that can undergo reversible dissociation into subunits. Because of this, the actual molecular weight of $8-9 \times 10^{6} \mathrm{Da}$ is generally not used for calculation of the molar ratio of hapten to carrier. For this purpose, 1 mole of KLH is defined as $100,000 \mathrm{~g}$.

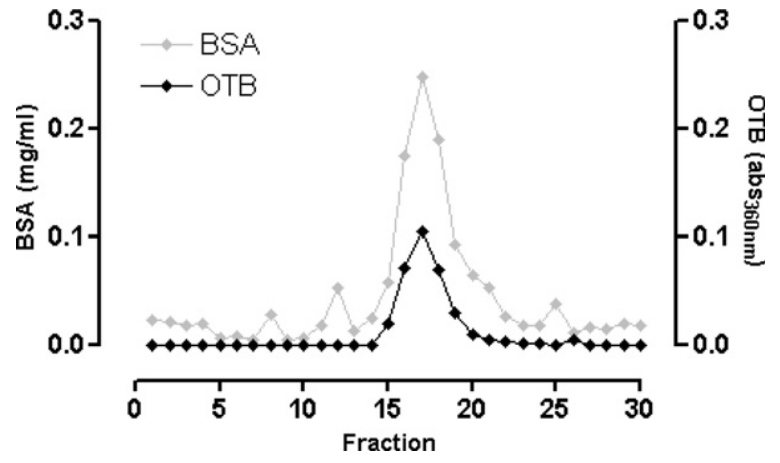

Fig. 2. Characterization of the OTB-BSA conjugate (representative curve).

of mice during the immunization period, nor were overt physiological changes observable. One mouse of the OTB-EDAC-KLH group died, without prior signs of disease, on day 34 and two animals suffered from the consequences of group housing. These animals were not used for further investigation.

\subsection{Immunization success}

The serum IgG titers of the immunized mice are shown in Fig. 3. For comparison, the IgG titers of two untreated $\mathrm{Balb} / \mathrm{c}$ mice were determined and yielded values of $0.62 \pm 0.42 \mathrm{mg} / \mathrm{ml}$ and $0.86 \pm 0.43 \mathrm{mg} / \mathrm{ml}$.

The controls indicated a successful immunization since PBS caused no stimulation of IgG production, whereas $\mathrm{KLH}$ alone was strongly immunogenic. OTB-CHMCKLH- as well as OTB-EDAC-KLH-immunized mice showed a similar pattern of $\mathrm{IgG}$ production to $\mathrm{KLH}-$ immunized mice. The OTB-EDAC-KLH antigen, despite containing less protein than its CHMC variant (Table 1), was able to increase the $\mathrm{IgG}$ titer in a comparable manner.

Extrapolation from the coupling efficiency data showed that approximately $10 \mu \mathrm{g}$ OTB per mouse and immunization step was sufficient to increase the $\operatorname{IgG}$ titer in the serum from $1.95 \pm 0.32 \mathrm{mg} / \mathrm{ml}$ (maximum of PBS control mice) to $7.38 \pm 0.29 \mathrm{mg} / \mathrm{ml}$ (OTB-EDAC-KLH).

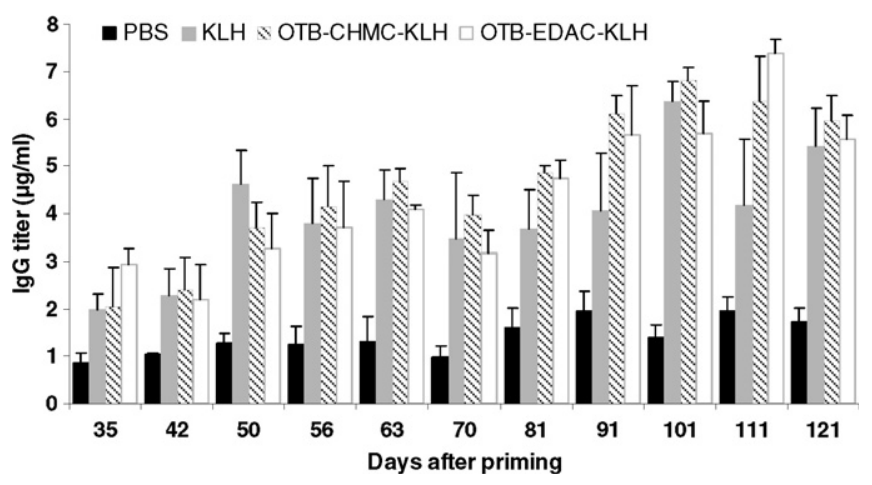

Fig. 3. Antibody titers of mice during immunization. Values represent a mean of at least $n=6$ pseudo-replicates (three determinations of the same serum samples in duplicate) $\pm \mathrm{SD}$. 


\subsection{Fusion procedure and hybridoma cell culture}

On day 81 after antigen priming, the first fusion of myeloma cells was carried out with spleen cells of a randomly chosen OTB-CHMC-KLH immunized mouse, because mice of this group showed an IgG titer approximately four-fold higher than that of PBS-control mice. A final antibody titer of $4.86 \pm 0.14 \mathrm{mg} / \mathrm{ml}$ was determined. For the second fusion on day 121, an OTB-EDAC-KLH immunized mouse with a serum titer of $5.68 \pm 0.69 \mathrm{mg} /$ $\mathrm{ml}$ was used.

A comparison of the number of spleen cells entering the fusion process with the number of non-fused splenocytes yielded a $29 \pm 7 \%$ fusion failure $(n=7)$.

Screening for antibody production was started 14 days after fusion. During the screening period of the first fusion, an attempt, as recommended by Campbell (1991), was made to acclimatize the cells to HAT-free conditions using gradually decreasing HAT concentrations, finally resulting in $0.5 \times \mathrm{HAT}$ in the medium. Positive clones of these hybridoma cells showed reduced antibody secretion. Hence, hybridoma cells from the second fusion were cultured without changing the medium composition during the complete screening and expansion procedure. Cryopreservation had no adverse impact on antibody production (Table 3).

\subsection{Selection of positive hybridoma clones by indirect ELISA}

Preliminary indirect ELISA experiments were conducted to determine optimal coating and detection procedures (data not shown), providing for the ELISA conditions described in the materials and methods section. A clone was selected as "positive" when the measured absorbance, minus the absorbance of the blocking buffer control, yielded a value above 1.0. An overview of the screening of the clones derived from fusions of the OTB-EDAC$\mathrm{KLH}$ and OTB-CHMC-KLH immunized mice is shown in Table 3. Only hybridoma clones that met the above mentioned criteria are listed. The clones were named in accor- dance with the accepted nomenclature, recommended by Baron (1992).

\subsection{Determination of cross-reactivity via indirect competitive ELISA}

The binding characteristics of the antibodies produced by the selected positive hybridoma cell clones (Table 3 ) were further characterized. Clear evidence of free OTB binding was exhibited by the antibodies produced by clone 2F1.E10, whereas all other antibodies showed no competition. Therefore, only the antibodies of this hybridoma clone were further characterized (Fig. 4).

This antibody species was selective for free OTB molecules at a concentration of $0.51 \pm 0.07 \mu \mathrm{M}$, where $50 \%$ of binding of OTB compared to control was achieved, had no affinity for EDAC, DL-phenylalanine or coumarin, but did display low cross-reactivity to OTA (3.3\%, Fig. 4). The detection limit was determined as $27 \pm 2 \mathrm{nM}$ OTB (mean $\pm 95 \%$ confidence interval, $n=6$ ).

In summary, the required conditions for optimum antibody production for ELISA were found to be as follows: four days of culturing, a cell density of $9.2 \times 10^{6} \pm$ $5.9 \times 10^{4}$ viable cells $/ \mathrm{ml}$, viability of $90 \pm 4 \%$ and an $\mathrm{IgG}$ titer of $22.2 \pm 4.0 \mu \mathrm{g} / \mathrm{ml}$, which was diluted to a final concentration of $0.3 \mu \mathrm{g} / \mathrm{ml}$.

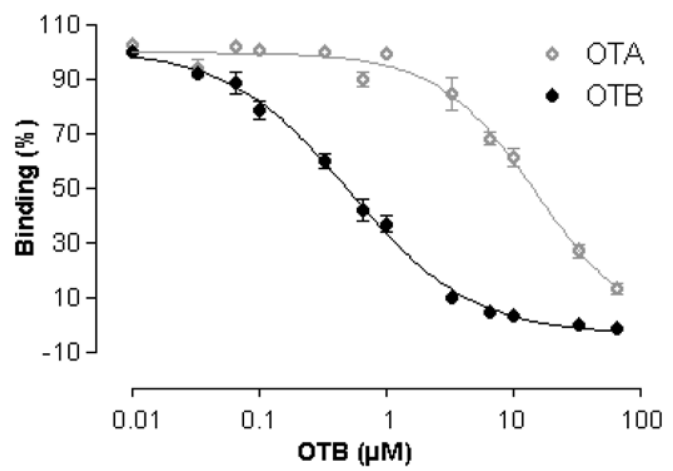

Fig. 4. Reactivity to OTB and OTA of antibodies produced by hybridoma clone 2F1.E10. Values represent the mean $\pm \mathrm{SD}, n=6$.

Table 3

Screening results of hybridoma cells resulting from fusions of spleenocytes from OTB-CHMC-KLH and OTB-EDAC-KLH immunized mice

\begin{tabular}{|c|c|c|c|c|c|c|c|c|}
\hline \multirow{3}{*}{$\begin{array}{l}\text { Positive clones } \\
\text { Positive clones (after lim. dilution) }\end{array}$} & \multicolumn{3}{|l|}{ OTB-CHMC-KLH } & \multicolumn{5}{|c|}{ OTB-EDAC-KLH } \\
\hline & 21 & & & 23 & & & & \\
\hline & 3 & & & 5 & & & & \\
\hline Monoclonal & 2F1.E10 & 23C3.D11 & 27B6.H10 & 3A7.H10 & 21E12.G3 & 23D11.C10 & 26G6.B11 & $26 \mathrm{H} 12 \mathrm{E} 11$ \\
\hline Expansion success & Yes & Yes & Yes & Yes & Yes & Yes & Yes & Yes \\
\hline Freezing success ${ }^{\mathrm{a}}$ & Yes & Yes & n.t. & Yes & Yes & Yes & Yes & Yes \\
\hline Viable cells/ml & $9.2 \times 10^{6} \pm 5.9 \times 10^{4}$ & $7.4 \times 10^{5}$ & $1.1 \times 10^{6}$ & $7.2 \times 10^{5}$ & $6.8 \times 10^{5}$ & $6.3 \times 10^{5}$ & $6.3 \times 10^{5}$ & $7.3 \times 10^{5}$ \\
\hline Viability (\%) & $90 \pm 4$ & 50.0 & 83.9 & 84.6 & 88.5 & 74.9 & 81.3 & 81.8 \\
\hline IgG titer $(\mu \mathrm{g} / \mathrm{ml})$ & $22.2 \pm 4.0$ & 9.0 & 0.01 & 0.5 & 0.6 & 0.5 & 0.3 & 0.6 \\
\hline Absorbances (direct use) & 2.16 & 0.82 & 0.01 & 1.12 & 1.83 & 1.13 & 0.86 & 0.87 \\
\hline Absorbances $(0.3 \mu \mathrm{g} \mathrm{IgG/ml})$ & 2.13 & 0.16 & 0.01 & 0.92 & 1.16 & 0.81 & 0.83 & 0.65 \\
\hline
\end{tabular}

Values without SD represent means of only two different determinations. n.t. = Not tested due to very low IgG titer.

${ }^{\text {a }}$ Freezing success $=$ cell clones showed proliferation and at least some antibody production after thawing and culture for at least 2 weeks. 
The antibody type produced by hybridoma clone 2F1.E10 was identified as IgG class 1 with the light chain belonging to the $\kappa$ configuration.

\section{Discussion}

As expected, the carbodiimide-linked OTB antigens elicited the desired humoral response in mice, resulting in an IgG titer approximately four times higher than the titer exhibited by the mice immunized with the solvent control. Due to the inherent maturation process of the antibody producing B-lymphocytes, antibodies directed against different epitopes of the antigenic macromolecule were produced. Only antibodies with a binding capacity for OTB were selected via indirect ELISA, using an OTBBSA conjugate as substrate. Two separate fusion procedures yielded eight cell clones producing antibodies capable of binding the OTB-BSA conjugate. Further analyses yielded one antibody species from a single hybridoma clone, able to selectively detect free OTB (detection limit $27 \mathrm{nM}, \mathrm{IC}_{50}=500 \mathrm{nM}$, cross-reactivity $($ OTA $)=3.3 \%$ ).

Antibodies produced against a hapten-carrier antigen result in antibodies specific for the hapten, the carrier and also for various mixtures of these molecules. Here, crossreactivities to the carrier could be ruled out because antibodies of this specificity found no compatible antigen in the screening procedure. No affinity for DL-phenylalanine or coumarin was seen, indicating that the antibody recognizes neither the phenylalanine nor the coumarin moiety but an epitope specific for the entire structure of ochratoxins. This epitope may involve the different substituents at the $\mathrm{C}_{5}$ of the isocoumarin moiety of ochratoxin, hydrogen in OTB and chlorine in OTA, which may, together with the $\alpha$-peptide bond, influence the overall charge of the molecule. This resulted in the preferential binding of OTB. The antibodies obtained from the other seven hybridoma cell clones, which were not further characterized, probably recognized a fragment common to both OTB and OTA, such as the region around the peptide bond.

The antibody species produced by hybridoma clone 2F1.E10 passed all selection assays successfully and fulfilled the desired criteria of selectively binding OTB in the nanomolar range. Furthermore, the cells could be expanded in vitro to yield the stable hybridoma cell line 2F1.E10 and long-term cryopreserved without detectable adverse effects.

To our knowledge, no data on the production of monoclonal antibodies against OTB have been published to date. In contrast, various groups have reported the production of monoclonal and polyclonal antibodies against OTA. OTA has been chosen as the primary target because of its great importance with regard to toxicity. The procedures used vary greatly with respect to animal species, antigen preparation and screening assays. The majority of the antibodies produced in these studies displayed cross-reactivity to OTB (Cho et al., 2005; Chu, 1976; Gyongyosi-
Horvath et al., 1996; Kawamura et al., 1989; Pestka et al., 1981; Rousseau et al., 1987; Yu et al., 2005). These studies produced antibodies against OTA with binding $\mathrm{IC}_{50} \mathrm{~s}$ in the low $\mathrm{ng} / \mathrm{ml}(\sim \mathrm{nM})$ range with cross-reactivities to OTB ranging from $0.8 \%$ to $31.7 \%$. Detection limits were in the $\mathrm{pg}-\mathrm{ng} / \mathrm{ml}$ range.

In the current work, the best antibodies yielded at least 30-fold higher specificity for OTB than for OTA at a $50 \%$ binding inhibition value of $500 \mathrm{nM}$ OTB. This corresponds to a cross-reactivity of $3.3 \%$. The cross-reactivity of the antibodies generated in this study is lower than that observed in most of the previous studies which generated antibodies against OTA (Cho et al., 2005; GyongyosiHorvath et al., 1996; Pestka et al., 1981; Yu et al., 2005). In contrast, other studies have reported more favorable detection limits (Cho et al., 2005; Chu, 1976; GyongyosiHorvath et al., 1996; Kawamura et al., 1989; Pestka et al., 1981; Rousseau et al., 1987; Yu et al., 2005).

Purified monoclonal antibodies with defined specificity can be employed in a broad array of laboratory assays such as RIA, ELISA and immunohistochemistry, as well as for immunoaffinity chromatography to elucidate contamination with ochratoxins in food items.

The amounts of OTA and OTB in food items range from $\mu \mathrm{g}-\mathrm{mg} / \mathrm{g}$, whereas in porcine and human serum concentrations of $0.05-14.4 \mathrm{ng}$ OTA $/ \mathrm{ml}$ have been measured (Hult et al., 1980; Hult et al., 1979; Hult et al., 1992; Krogh, 1987; Studer-Rohr et al., 2000). The OTB antibodies generated in the current study are capable of detecting nanomolar concentrations of OTB. Therefore, they provide adequate sensitivity to detect OTB in (extracted) food samples or in concentration-enhanced serum samples, but they are most likely not sufficiently sensitive to detect OTB directly in serum samples containing pM concentrations.

A follow-up study including further investigations for complete characterization of the antibodies produced by the stable hybridoma cell line 2F1.E10 is currently in progress. This will include large scale antibody production, purification and long-term storage and will also investigate potential laboratory applications, e.g., ELISA and immunohistochemistry in tissue slices and cell cultures, immunoblotting, as well as recovery of ochratoxins in mixed samples extracted from contaminated dietary products.

In conclusion, the stable hybridoma cell line 2F1.E10, which secretes a sensitive and specific monoclonal OTBantibody, was generated. These antibodies were used to establish an indirect competitive ELISA that can specifically detect OTB in the nanomolar to micromolar concentration range.

\section{Acknowledgements}

We would like to thank M.E. Stack, US FDA, Washington, DC, for providing highly purified ochratoxin A and B, T. Hartung and co-workers, University of Konstanz, 
Germany, for carrying out the mycoplasma PCR and C. Stürmer, University of Konstanz, Germany, for the kind gift of the myeloma cell line.

This project was partially funded by the foundation "Umwelt \& Wohnen" at the University of Konstanz, Germany.

\section{References}

Baron, D., 1992. Production of hybridomas. In: Peters, J.H., Baumgarten, H. (Eds.), Monoclonal Antibodies. Springer-Verlag, Heidelberg, p. 137.

Baumgarten, H., 1992. Taking blood and isolating cells. In: Peters, J.H., Baumgarten, H. (Eds.), Monoclonal Antibodies. Springer-Verlag, Heisenberg, p. 71.

Baumgartner, S., Wilchek, M., 1955. The use of carbodiimides in the preparation of immunizing conjugates. J. Am. Chem. Soc. 77, 1067.

Bazin, R., Lemieux, R., 1989. Increased proportion of B cell hybridomas secreting monoclonal antibodies of desired specificity in cultures containing macrophage-derived hybridoma growth factor (IL-6). J. Immunol. Methods 116 (2), 245-249.

Campbell, A.M., 1991. Selection and cloning. In: van Vliet, P.C. (Ed.), Laboratory Techniques in Biochemistry and Molecular Biology. Elsevier, Amsterdam, p. 225.

Cho, Y.-J., Lee, D.-H., Kim, D.-O., Min, W.-K., Bong, K.-T., Lee, G.-G., Seo, J.-H., 2005. Production of a monoclonal antibody against ochratoxin A and its application to immunochromatographic assay. J. Agric. Food Chem. 53, 8447-8451.

Chu, F.S., 1976. Production of antibody against ochratoxin A. Appl. Environ. Microbiol. 31 (6), 831-835.

Dietrich, D.R., O'Brien, E., Stack, M.E., Heussner, A.H., 2001. Speciesand sex-specific renal cytotoxicity of ochratoxin A and B in vitro. Exp. Toxicol. Pathol. 53 (2-3), 215-225.

Doster, R.C., Sinnhuber, R.O., Wales, J.H., 1972. Acute intraperitoneal toxicity of ochratoxin A and B in rainbow trout (Salmo gairdneri). Food Cosmet. Toxicol. 10, 85-92.

Doster, R.C., Sinnhuber, R.O., Pawlowski, N.E., 1974. Acute intraperitoneal toxicity of ochratoxin A and B derivatives in rainbow trout (Salmo gairdneri). Food Cosmet. Toxicol. 12, 499-505.

Gyongyosi-Horvath, A., Barna-Vetro, I., Solti, L., 1996. A new monoclonal antibody detecting ochratoxin $\mathrm{A}$ at the picogram level. Lett. Appl. Microbiol. 22 (2), 103-105.

Heussner, A.H., Dietrich, D.R., O'Brien, E., 2006. In vitro investigation of individual and combined cytotoxic effects of ochratoxin $\mathrm{A}$ and other selected mycotoxins on renal cells. Toxicol. In Vitro. 20 (3), 332-341.

Hilwig, I., Gropp, A., 1972. Staining of constitutive heterochromatin in mammalian chromosomes with a new fluorochrome. Exp. Cell Res. 75 (1), 122-126

Hult, K., Hokby, E., Hagglund, U., Gatenbeck, S., Rutqvist, L., Sellyey, G., 1979. Ochratoxin A in pig blood: method of analysis and use as a tool for feed studies. Appl. Environ. Microbiol. 38 (5), 772-776.

Hult, K., Hokby, E., Gatenbeck, S., Rutqvist, L., 1980. Ochratoxin A in blood from slaughter pigs in Sweden: use in evaluation of toxin content of consumed feed. Appl. Environ. Microbiol. 39 (4), 828-830.

Hult, K., Hokby, E., Sellyey, G., Rutqvist, L., Gatenbeck, S., 1992. Ochratoxin A occurrence in slaughter-pigs in Sweden and its use as a tool for feed screening programs. J. Environ. Pathol. Toxicol. Oncol. $11(2), 39-40$

Kawamura, O., Sato, S., Kajii, H., Nagayama, S., Ohtani, K., Chiba, J., Ueno, Y., 1989. A sensitive enzyme-linked immunosorbent assay of ochratoxin A based on monoclonal antibodies. Toxicon 27 (8), 887 897.

Krogh, P., 1987. Ochratoxins in Food. In: Krogh, P. (Ed.), Mycotoxins in Food. Academic Press, London, p. 97.

Mally, A., Keim-Heusler, H., Amberg, A., Kurz, M., Zepnik, H., Mantle, P., Volkel, W., Hard, G.C., Dekant, W., 2005. Biotransformation and nephrotoxicity of ochratoxin B in rats. Toxicol. Appl. Pharmacol. 206 (1), 43-53.

McGill, M., Rowan, A., 1989. Refinement of monoclonal antibody production and animal well-being. ILAR J. 31 (1).

O'Brien, E., Dietrich, D.R., 2005a. Mycotoxins affecting the kidney. In: Tarloff, J., Lash, L. (Eds.), Toxicology of the Kidney. CRC Press, Boca Raton, Florida, USA, p. 895.

O'Brien, E., Dietrich, D.R., 2005b. Ochratoxin A: the continuing enigma. Crit. Rev. Toxicol. 35 (1), 33-60.

O'Brien, E., Heussner, A.H., Dietrich, D.R., 2001. Species-, sex-, and cell type-specific effects of ochratoxin A and B. Toxicol. Sci. 63 (2), 256264.

Oi, V.T., Herzenberg, L.A., 1980. Immunoglobulin-producing hybrid cell lines. In: Mishell, B.B., Shiigi, S.M. (Eds.), Selected Methods in Cellular Immunology. Freeman, San Fransisco, p. 351.

Pestka, J.J., Steinert, B.W., Chu, F.S., 1981. Enzyme-linked immunosorbent assay for detection of ochratoxin A. Appl. Environ. Microbiol. 41 (6), 1472-1474.

Pfohl-Leszkowicz, A., Petkova-Bocharova, T., Chernozemsky, I.N., Castegnaro, M., 2002. Balkan endemic nephropathy and associated urinary tract tumours: a review on aetiological causes and the potential role of macotoxins. Food Addit. Contam. 19 (3), 282-302.

Rousseau, D.M., Candlish, A.G., Slegers, G.A., Van Peteghem, C.H., Stimson, W.H., Smith, J.E., 1987. Detection of ochratoxin A in porcine kidneys by a monoclonal antibody-based radioimmunoassay. Appl. Environ. Microbiol. 53 (3), 514-518.

Sheehan, J.C., Hess, J.P., 1955. A new method of forming peptide bonds. J. Am. Chem. Soc. 77, 1067.

Stefanovic, V., Toncheva, D., Atanasova, S., Polenakovic, M., 2006. Etiology of Balkan endemic nephropathy and associated urothelial cancer. Am. J. Nephrol. 26, 1-11.

Stoev, S.D., 1998. The role of ochratoxin A as a possible cause of Balkan endemic nephropathy and its risk evaluation. Vet. Hum. Toxicol. 40 (6), 352-360

Stoev, S.D., Hald, B., Mantle, P.G., 1998. Porcine nephropathy in Bulgaria: a progressive syndrome of complex or uncertain (mycotoxin) aetiology. Vet. Rec. 142, 190-194.

Stoev, S.D., Paskalev, M., Macdonald, S., Mantle, P.G., 2002. Experimental one year ochratoxin A toxicosis in pigs. Exp. Toxicol. Pathol. $53,481-487$.

Størmer, F.C., Kolsaker, P., Holm, H., Rogstad, S., Elling, F., 1985. Metabolism of ochratoxin B and its possible effects upon the metabolism and toxicity of ochratoxin A in rats. Appl. Environ. Microbiol. 49 (5), 1108-1112.

Studer-Rohr, I., Schlatter, J., Dietrich, D.R., 2000. Kinetic parameters and intraindividual fluctuations of ochratoxin A plasma levels in humans. Arch. Toxicol. 74 (9), 499-510.

Tatu, C.A., Orem, W.H., Finkelman, R.B., Feder, G.L., 1998. The etiology of Balkan endemic nephropathy: still more questions than answers. Environ. Health Perspect. 106 (11), 689-700.

Wuerzner, R., Baumgarten, H., Peters, J.H., 1992. Cryopreservation of cells. In: Peters, J.H., Baumgarten, H. (Eds.), Monoclonal Antibodies. Springer-Verlag, Heidelberg.

Yu, F.-Y., Chi, T.-F., Liu, B.-H., Su, C.-C., 2005. Development of a sensitive enzyme-linked immunosorbent assay for the determination of ochratoxin A. J. Agric. Food Chem. 53, 6947-6953. 